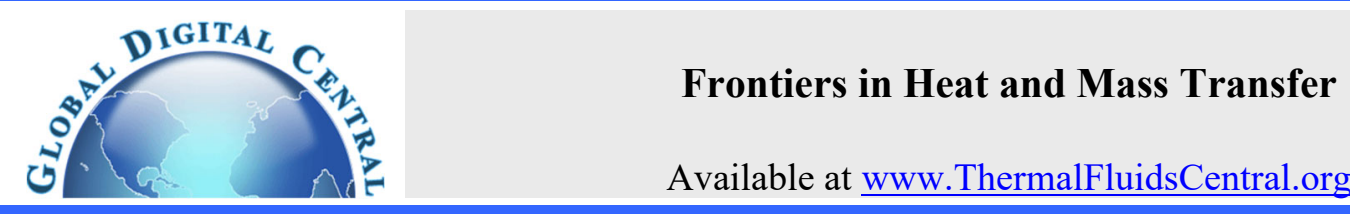

\title{
EXPERIMENTAL INVESTIGATION AND MATHEMATICAL MODELING OF CONVECTIVE DRYING KINETICS OF WHITE RADISH
}

\author{
Abhishek Dasore $^{\mathrm{a}^{*}}$, Ramakrishna Konijeti $^{\mathrm{b}}$, Naveen Puppala ${ }^{\mathrm{c}}$ \\ ${ }^{a}$ Research Scholar, Department of Mechanical Engineering, Koneru Lakshmaiah Education Foundation, Guntur, Andhra Pradesh, 522502, India \\ ${ }^{b}$ Professor, Department of Mechanical Engineering, Koneru Lakshmaiah Education Foundation, Guntur, Andhra Pradesh, 522502, India \\ ${ }^{c}$ Professor, Agricultural Science Centre at Clovis, College of Agricultural, Consumer and Environmental Sciences, NMSU, NM, 88101, USA
}

\begin{abstract}
The influence of air temperature on drying kinetics of radish slices in a bench scale convective tray dryer was examined experimentally and suitable drying model was developed. The experiments of drying of radish slices were conducted at 40,50 and $60{ }^{\circ} \mathrm{C}$ with an air velocity of $2 \mathrm{~m} / \mathrm{s}$. The moisture transport from the radish slices are defined by Fick's diffusion model and effective diffusivity changes between $3.3-5.55 \times 10^{-8} \mathrm{~m}^{2} / \mathrm{min}$. An Arrhenius relation with activation energy value of $18.49 \mathrm{~kJ} / \mathrm{mol}$ expressed the effect of temperature on the diffusivity. Also, drying data were fitted to ten commonly used thin-layer drying models. The statistical parameters coefficient of determination $\left(R^{2}\right)$ and root mean square error $(R M S E)$ were examined for evaluating the models. Among the models, Hii et al. model was the best to explain the single layer drying of white radish slices.
\end{abstract}

Keywords: Air temperature, Forced air convective drying, Thin-layer mathematical modeling, Transport properties, White Radish.

\section{INTRODUCTION}

Root crops such as radish, carrot, beets, onion, garlic etc. are being consumed either raw or cooked with other vegetables. Radish (Raphanus sativus L.) is popular salad crop for fresh market and home gardening. In India, they are chiefly cultivated in warm-humid states like Uttar Pradesh, Punjab, Maharashtra and Gujarat. Radish roots are considered to be good for patients suffering from gallbladder ailments, hemorrhoids, jaundice enlarged spleen and liver trouble (Benjamin et al., 2003).

Drying is a common technique employed in processing of the white radish. Dried radish is conventionally produced by sun drying. But the main limitation to sun drying is it requires a longer drying time and it is difficult to monitor the moisture content of sample (Lee et al., 2006). In addition, quality of products degrades in sun drying, due to wind-borne dust and dirt, infestation by insects, rodents and other animals (ElBeltagy et al. 2007). Forced convective drying provides an alternative to traditional sun drying. It allows controlled removal of moisture under low pressure. Simultaneously with forced convective drying it is possible to have a higher drying rate and lower drying temperature.

Knowledge of the drying kinetics of the radish is essential to design, optimize and control the process of drying. It is also necessary to investigate the forced convective drying characteristics of the radish to evaluate the process parameters and feasibility of convective drying for improving the quality of the dried radish. Although several studies have been carried out to investigate forced convective drying characteristics of various food materials (Akpinar et al. 2003, Samira et al. 2016, Agarry et al. 2005, Doymaz 2007, Gokhale and Lele 2011, Darvishi et al. 2016, Aregbesola et al. 2015, Waheed and Komolafe 2019), no data on forced convective drying behavior of radish slices are available for the engineering design of drying.

The objective of this experimental work is to determine the effect of drying temperature on drying characteristics of radish slices. Also, an appropriate thin-layer drying model is selected for describing the drying process of radish in thin layers through non-linear regression analysis and computed effective moisture diffusivity and activation energy of radish samples.

\section{MATERIALS AND METHODS}

\subsection{Sample preparation}

Fresh radishes were procured from nearby market and kept at room temperature before use. Prior to dehydration, the radishes were thoroughly washed to remove the dirt before peeling manually. The radishes were cut into slices having dimensions $(50 \pm 0.2) \times(50 \pm$ $0.2) \times 2 \mathrm{~mm}$. The thickness of the slices was measured using a Vernier calipers. The initial moisture content of the radish slices was found to be $15.5 \pm 0.5 \mathrm{~kg} \mathrm{w} / \mathrm{kg} \mathrm{ds}$ by drying the samples in an oven at $105^{\circ} \mathrm{C}$ for $24 h$ (Ozbek and Dadali 2007).

\subsection{Drying equipment}

In direct drying process as that of in convective tray dryer, the sample will be in direct contact with drying medium and effective drying is carried out when compared to indirect drying. Moreover, convective tray dryer is simple and relatively low-cost technique (Anwar and Tiwari 2001, Akpinar and Toraman, 2016, Ratiya et al. 2011). Hence in the present work, drying was performed in a laboratory-scale induced draft convective tray dryer at Koneru Lakshmaiah Education Foundation, India. The dryer consists of a variable speed blower, heating control system, air duct, tray, temperature, humidity, weight and velocity measuring instruments. The dryer is equipped with controllers for monitoring the temperature and air flow velocity. Air was drawn into the duct by a motor driven axial flow induced blower. In the tunnel of the dryer there are carriers for trays with samples, which are connected to a balance. The balance is placed outside the dryer, which determines and 
displays sample weight continuously during the operation. A digital anemometer is used to measure the airflow velocity. the heating systems consists of three electric heaters each of $1 \mathrm{~kW}$ placed inside the duct. A rheostat is used to adjust the drying chamber temperature. The drying chamber is constructed in concentric form with an annulus, insulated with glass wool. Temperatures are measured using T-type thermocouples which are manually controlled by a six-channel temperature indicator with an accuracy of $\pm 0.5^{\circ} \mathrm{C}$.

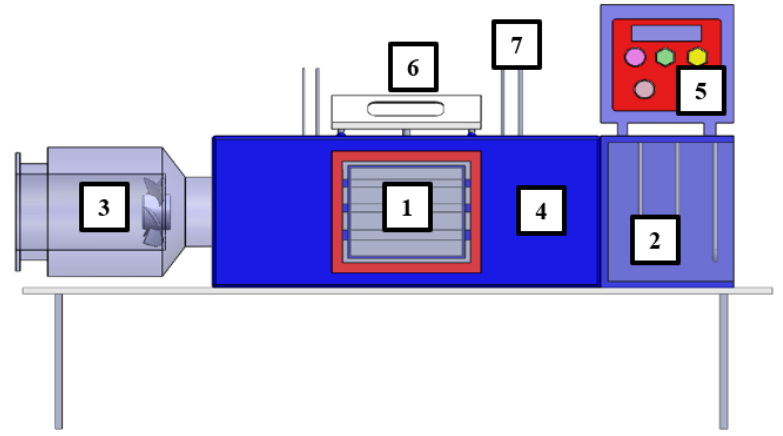

Fig. 1 Bench-scale convective tray dryer.

1- Drying space; 2- Heating coils; 3- Induced draft fan; 4- Air duct; 5- control switches; 6- Digital weighing balance; 7- Measuring instruments

\subsection{Experimental test procedure}

Drying equipment was operated at no load conditions till it reaches steady state. Later $500 \mathrm{~g}$ of radish slices is equally distributed over the trays and kept inside the drying chamber. After every 10 minutes, the weight loss of radish slices was recorded. This experimental study was continued till no change in the weight of the product is noticed for three successive readings.

\subsection{Experimental uncertainty}

Errors and uncertainties in the experiments can arise from instrument selection, condition, calibration, environment and human factors (Midilli 2001b). In drying experiments of white radish slices, the temperatures, velocity of drying air, weight losses were measured with appropriate instruments. During the measurements of the parameters, the uncertainties occurred were presented in Table 1 .

Table 1 Uncertainties of the parameters during drying of radish slices

\begin{tabular}{|l|c|}
\hline \multicolumn{1}{|c|}{ Parameter } & Uncertainty \\
\hline Temperature between trays & $\pm 0.4^{\circ} \mathrm{C}$ \\
\hline Velocity measurement & $\pm 0.2 \mathrm{~m} / \mathrm{s}$ \\
\hline Mass loss measurement & $\pm 0.01 \mathrm{~g}$ \\
\hline Relative humidity & $\pm 3 \%$ \\
\hline
\end{tabular}

\section{MATHEMATICAL MODELING}

\subsection{Drying kinetics}

The moisture transfer from radish to surrounding hot air is mathematically analogous to the flow of heat from a hot body immersed in a cool fluid that is represented by Newton's law of cooling (Gokhale and Lele 2011). Therefore, the drying rate is proportional to the difference in moisture content between the material being dried and the equilibrium moisture content $\left(M_{e}\right)$ which is dependent on the drying air conditions.

The moisture ratio $M^{*}$ and drying rate $D R$ of radish slices during the thinlayer drying experiments were calculated using Eq. (1) and Eq. (2) (Midilli 2001a, Akpinar 2002)

$$
\begin{aligned}
M^{*} & =\frac{M_{\tau}-M_{e}}{M_{o}-M_{e}} \\
D R & =\frac{M_{\tau+d \tau}-M_{\tau}}{d \tau}
\end{aligned}
$$

Table 2 Selected thin-layer drying models for describing radish drying data.

\begin{tabular}{|c|c|c|}
\hline Model Name & Thin-layer drying model & References \\
\hline Lewis model & $M^{*}=e^{(-k \tau)}$ & $\begin{array}{c}\text { El-Beltagy } \\
\text { et al. } \\
(2007)\end{array}$ \\
\hline $\begin{array}{c}\text { Single term } \\
\text { model }\end{array}$ & $M^{*}=e^{\left(-k \tau^{n}\right)}$ & $\begin{array}{c}\text { Akoy et al. } \\
(2014)\end{array}$ \\
\hline $\begin{array}{c}\text { Logarithmic } \\
\text { model }\end{array}$ & $M^{*}=a e^{(-k \tau)}+c$ & $\begin{array}{c}\text { Hashim et } \\
\text { al. (2014) }\end{array}$ \\
\hline $\begin{array}{c}\text { Two-term } \\
\text { model }\end{array}$ & $M^{*}=a e^{\left(-k_{1} \tau\right)}+b e^{\left(-k_{2} \tau\right)}$ & $\begin{array}{c}\text { Kaur and } \\
\text { Singh } \\
(2014)\end{array}$ \\
\hline $\begin{array}{c}\text { Wang and } \\
\text { Singh Model }\end{array}$ & $M^{*}=1+a \tau+b \tau^{2}$ & $\begin{array}{c}\text { Sacilik } \\
(2007)\end{array}$ \\
\hline $\begin{array}{c}\text { Verma model } \\
\text { Mage model }\end{array}$ & $M^{*}=a e^{(-k \tau)}+(1-a) e^{(-g \tau)}$ & $\begin{array}{c}\text { Omolola et } \\
\text { al. (2014) }\end{array}$ \\
\hline $\begin{array}{c}\text { Midilli model } \\
(2006)\end{array}$ \\
\hline $\begin{array}{c}\text { Diffusion } \\
\text { approach } \\
\text { model }\end{array}$ & $M^{*}=a e^{(-k \tau)}+b \tau$ & $\begin{array}{c}\text { Ayadi et al. } \\
(2014)\end{array}$ \\
\hline $\begin{array}{c}\text { Hii et al. model } \\
{ }^{*}=a e^{(-k \tau)}+(1-a) e^{(-k b \tau)}\end{array}$ & $\begin{array}{c}\text { Yaldyz and } \\
\text { Ertekyn } \\
(2007)\end{array}$ \\
\hline
\end{tabular}

Drying curves were fitted to ten well-known thin-layer drying models in Table 2. to select the best suited model for describing the drying characteristics of radish slices. Non-linear square regression analysis was performed using MATLAB 18.1 (MathWorks, Inc., 1984, Natick, USA) computer program. The goodness of the fit can be checked with different statistical methods such as Correlation coefficient $(R)$, Coefficient of determination $\left(R^{2}\right)$, Chi square $\left(\chi^{2}\right)$, Sum of Squares for Error (SSE), Root Mean Square Error (RMSE), Mean Absolute Percentage Error $(M A P E)$ and Mean Bias Error $(M B E)$ respectively. Of all these statistical indicators, the most widely used method in literature is $\mathrm{R}^{2}$ and RMSE. Hence, in the present work, the goodness of the fit was determined by using coefficient of determination $\left(R^{2}\right)$ and root mean square error (RMSE) (Wang et al. 2007a, Vedavathi et al. 2019, Kiran et al. 2019, Midilli et al. 2002)

These parameters can be calculated by Eq. (3-5). The higher values of $R^{2}$ and the lower values of $R M S E$ are chosen as the criteria for goodness of fit in the present study (Yaldiz et al. 2001, Wang et al. 2007b, Lahsasni et al. 2004, Abhishek et al. 2019).

$$
\begin{aligned}
& R^{2}=1-\frac{\sum_{i=1}^{N}\left(M_{\text {pre }, i}^{*}-M_{\text {exp }, i}^{*}\right)^{2}}{\sum_{i=1}^{N}\left(M_{\exp , i}^{*}-M_{\text {avg }}^{*}\right)^{2}} \\
& R M S E=\left[\frac{1}{N} \sum_{i=1}^{N}\left(M_{\text {pre }, i}^{*}-M_{\exp , i}^{*}\right)^{2}\right]^{1 / 2}
\end{aligned}
$$




\subsection{Effective moisture diffusivity}

From the drying data analysis, it was recognized that the air-drying of radish didn't consist of constant rate drying period. Hence, Fick's II law of unsteady state diffusion in Eq. (5) can be used to interpret the experimental results.

For an infinite slab and uniform initial moisture concentration, Crank (1975) proposed analytical solution Eq. (6) for Eq. (5) with the following suitable boundary conditions.

$$
\begin{gathered}
\tau=0 \& 0<z<L \Rightarrow M=M_{o} \\
\tau>0 \& z=0 \Rightarrow \frac{d M}{d \tau}=0 \\
\tau>0 \& z=L \Rightarrow M=M_{e} \\
\frac{\partial M}{\partial \tau}=D_{e f f} \frac{\partial^{2} M}{\partial z^{2}} \\
M^{*}=\frac{8}{\pi^{2}} \sum_{n=0}^{\infty} \frac{1}{(2 n+1)^{2}} e^{\left(-(2 n+1)^{2} \pi^{2} \frac{D_{e f f}}{4 L^{2}} \tau\right)}
\end{gathered}
$$

$D_{\text {eff }}$ mainly varies with internal conditions like product's temperature, the moisture content and the structure. By considering very low thickness to width ratio, the sample was assumed to be infinite slab. For longer drying periods, the Eq. (6) can be reduced to Eq. (7).

$$
\ln \left(M^{*}\right)=\ln \left(\frac{8}{\pi^{2}}\right)-\pi^{2} \frac{D_{\text {eff }}}{4 L^{2}} \tau
$$

\subsection{Activation energy}

Many researchers studied the effect of temperature on $D_{\text {eff }}$ and this effect can be generally described by an Arrhenius equation (Madamba et al. 1996).

$$
D_{\text {eff }}=D_{o} \exp \left(-10^{3} \frac{E_{a}}{R(T+273.15)}\right)
$$

The value of $E_{a}$ shows the sensibility of the diffusivity against temperature. The greater value of $E_{a}$ means more sensibility of $D_{\text {eff }}$ to temperature (Kaymak-Ertekin 2002). Here, $D_{o}$ is the pre-exponential factor of the Arrhenius equation $\left(\mathrm{m}^{2} / \mathrm{s}\right)$ that is generally defined as the reference diffusion coefficient at infinitely high temperature.

\section{RESULTS AND DISCUSSIONS}

Single layer radish slices with thickness of $2 \mathrm{~mm}$ are dried in an induced draft convective tray dryer at the drying temperatures of 40,50 and $60{ }^{\circ} \mathrm{C}$. The radish slices of $15.67 \mathrm{kgw} / \mathrm{kgds}$ were dried to a final moisture content of $0.03 \mathrm{kgw} / \mathrm{kgds}$. The variations in the moisture content as a function of the drying time at various drying temperatures are presented in Figure 2. It can be seen that moisture content decreases continually with drying time. As expected, drying air temperature has a significant effect on the moisture content of radish slices. The drying times required to remove $15.64 \mathrm{kgw} / \mathrm{kgds}$ quantity of moisture from radish slices were 450, 320 and $260 \mathrm{~min}$ at the drying air temperatures of 40,50 and $60{ }^{\circ} \mathrm{C}$, respectively.

Figure 3. shows the change in moisture ratio of radish slices with time at different temperatures. The results indicate that higher air-drying temperature resulted in greater slope of the curve and shorter drying time. The reason for this could be, increased air-drying temperature leads to an improved temperature gradient and surface evaporation rate, accelerating moisture diffusion from the center to the surface. These results are consistent with another study, where the decreased drying time was attributed to increase of the air-drying temperature (Akpinar et al. 2003).

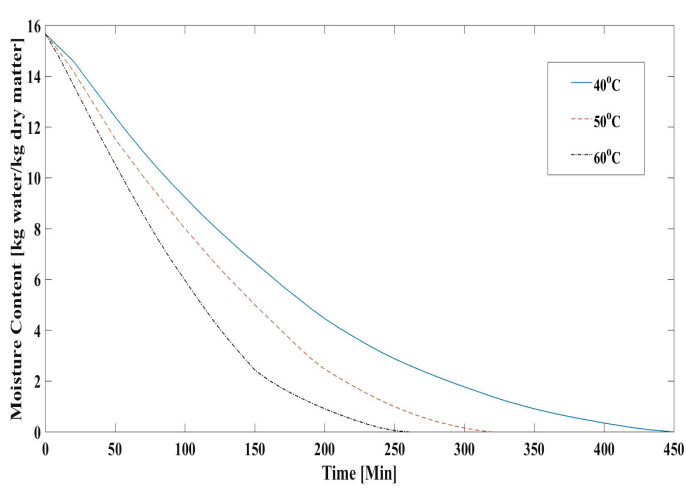

Fig. 2 Moisture content of radish slices as a function of time at different drying temperatures

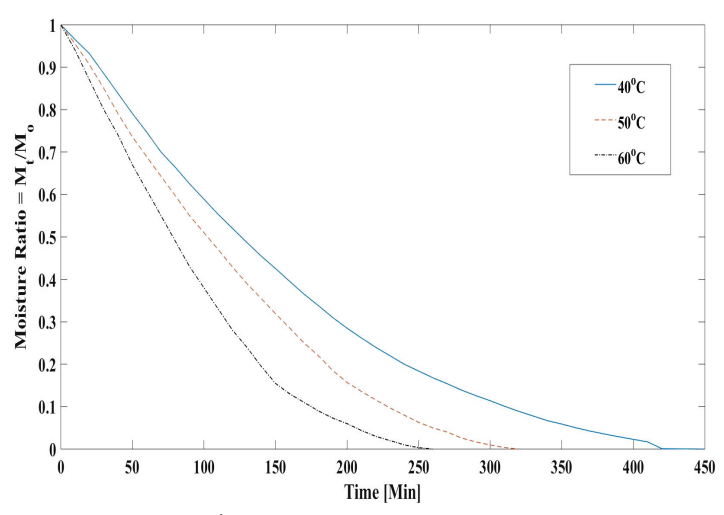

Fig. 3 Variation of $M^{*}$ of white radish slices with $\tau$ for different temperatures

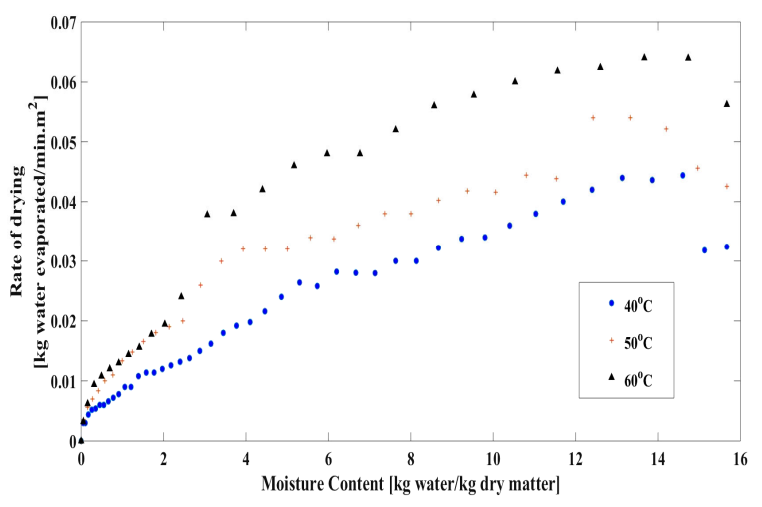

Fig. 4 Drying rate curves of white radish slices at different temperatures

The changes in the drying rates with moisture content for the radish slices are shown in Figure 4. It is apparent that the drying rate decreases continuously with decreasing moisture content or increasing drying time. It is also noted that the drying rate increased with the increase in drying air temperature. The drying rate was greater for radish slices dried at a higher temperature than for radish slices dried at a lower temperature for the same average moisture content of the radishes. Consequently, the drying time decreased at a higher drying air temperature condition. Similar characteristics for variation of drying rate with moisture content were reported by Xiao-Kang et al. (2012), Manuel Cuevas et al. (2019).

Sliced radishes did not exhibit a constant-rate drying period and all the drying operations are seen to occur in the falling rate period. This is due to the quick removal of moisture from the skin of radish slices and shows the diffusion dominant drying phenomena. At the beginning of the drying process, the drying rate was very high, but decreased as the 
moisture content approached an equilibrium. Similar results have been presented for many agricultural products (Kaya et al. 2007, Correia et al. 2015).

The moisture content data from the drying experiment were converted into the moisture ratio $M^{*}$ and then fitted to the selected thinlayer drying models in Table 2 . The statistical results of the different models, including the comparison criteria used to evaluate goodness of the fit, viz., the values of the coefficient of determination $\left(R^{2}\right)$ and root mean square error (RMSE) are presented in Table 3. Based on the criteria of the highest $R^{2}$ and the lowest $R M S E$, the best model describing the thin-layer drying characteristics of radish slices was selected. For all the experiments, the $R^{2}$ and $R M S E$ values for the models changed between 0.965 and $0.9995,0.007$ and 0.06 , respectively. From Table 3, the highest $R^{2}$ values and the lowest value of $R M S E$ values were obtained from the Hii et al. model. The $R^{2}$ and $R M S E$ values of Hii et al. model vary between 0.999 and $0.9995,0.0071$ and 0.01 , respectively. According to these results, the Hii et al. model was selected as the appropriate model to represent the drying behavior of radish slices in thin layers.

Table 3 Selected thin-layer drying models for describing radish drying data.

\begin{tabular}{|c|c|c|c|c|c|c|c|c|}
\hline \multirow{2}{*}{ Model } & \multirow{2}{*}{$\begin{array}{c}\mathrm{T} \\
\left({ }^{\circ} \mathrm{C}\right)\end{array}$} & \multirow{2}{*}{\multicolumn{5}{|c|}{ Coefficients }} & \multicolumn{2}{|c|}{ Statistics } \\
\hline & & & & & & & $R^{2}$ & RMSE \\
\hline \multirow{4}{*}{ Lewis } & & $k$ & & & & & & \\
\hline & 40 & 0.006317 & & & & & 0.9773 & 0.04623 \\
\hline & 50 & 0.008034 & & & & & 0.965 & 0.0593 \\
\hline & 60 & 0.01061 & & & & & 0.9667 & 0.05892 \\
\hline \multirow{4}{*}{ Page } & & $k$ & $n$ & & & & & \\
\hline & 40 & 0.001303 & 1.302 & & & & 0.998 & 0.01378 \\
\hline & 50 & 0.001165 & 1.389 & & & & 0.9955 & 0.02148 \\
\hline & 60 & 0.001565 & 1.407 & & & & 0.9977 & 0.01593 \\
\hline \multirow{4}{*}{ Single term } & & $a$ & $k$ & & & & & \\
\hline & 40 & 1.09 & 0.006865 & & & & 0.9858 & 0.03698 \\
\hline & 50 & 1.097 & 0.008786 & & & & 0.9754 & 0.05047 \\
\hline & 60 & 1.098 & 0.01159 & & & & 0.9769 & 0.05001 \\
\hline \multirow{4}{*}{ Logarithmic } & & $a$ & $k$ & $c$ & & & & \\
\hline & 40 & 1.191 & 0.004916 & -0.151 & & & 0.9986 & 0.01162 \\
\hline & 50 & 1.308 & 0.005271 & -0.274 & & & 0.9978 & 0.0154 \\
\hline & 60 & 1.247 & 0.007692 & -0.203 & & & 0.9956 & 0.02236 \\
\hline \multirow{4}{*}{ Two term } & & $a$ & $k_{1}$ & $b$ & & $k_{2}$ & & \\
\hline & 40 & 19.89 & 0.01117 & -18.8 & & 0.011594 & 0.9975 & 0.01592 \\
\hline & 50 & 1.137 & 0.0091 & -0.136 & & 2.138 & 0.9795 & 0.04761 \\
\hline & 60 & -0.1542 & 2.186 & 1.154 & & 0.01216 & 0.9825 & 0.04544 \\
\hline \multirow{4}{*}{$\begin{array}{l}\text { Wang and } \\
\text { Singh }\end{array}$} & & $a$ & $b$ & & & & & \\
\hline & 40 & -0.004597 & $5.36 e^{-06}$ & & & & 0.999 & 0.00961 \\
\hline & 50 & -0.005787 & $8.225 e^{-06}$ & & & & 0.9994 & 0.00818 \\
\hline & 60 & -0.00769 & $1.477 e^{-05}$ & & & & 0.9984 & 0.01298 \\
\hline \multirow{4}{*}{ Verma } & & $a$ & $k$ & $g$ & & & & \\
\hline & 40 & 1.118 & 0.007036 & 10.89 & & & 0.9883 & 0.03394 \\
\hline & 50 & 1.137 & 0.0091 & 3.185 & & & 0.9795 & 0.04681 \\
\hline & 60 & 1.154 & 0.01216 & 3.129 & & & 0.9825 & 0.04448 \\
\hline \multirow{4}{*}{ Midilli } & & $a$ & $k$ & $b$ & & & & \\
\hline & 40 & 1.044 & 0.005553 & -0.0002 & & & 0.9982 & 0.01344 \\
\hline & 50 & 1.036 & 0.006348 & -0.0005 & & & 0.9972 & 0.01738 \\
\hline & 60 & 1.048 & 0.008947 & -0.0005 & & & 0.9942 & 0.02458 \\
\hline \multirow{4}{*}{$\begin{array}{l}\text { Diffusion } \\
\text { Approach }\end{array}$} & & $a$ & $k$ & $b$ & & & & \\
\hline & 40 & 209.8 & 0.00276 & 0.995 & & & 0.9978 & 0.01457 \\
\hline & 50 & 225.5 & 0.00283 & 0.994 & & & 0.9973 & 0.01709 \\
\hline & 60 & 21.6 & 0.02004 & 1.041 & & & 0.9964 & 0.02022 \\
\hline \multirow{4}{*}{ Hii et al. } & & $a$ & $k_{1}$ & $b$ & $k_{2}$ & $n$ & & \\
\hline & 40 & 0.7894 & 0.00012 & 0.1997 & 0.0013 & 1.709 & 0.9995 & 0.00709 \\
\hline & 50 & 0.7703 & $4.102 e^{-05}$ & 0.2133 & 0.0008 & 1.994 & 0.9995 & 0.0077 \\
\hline & 60 & 0.9406 & 0.00072 & 0.059 & 11.37 & 1.556 & 0.999 & 0.01085 \\
\hline
\end{tabular}


Figure 5 compare the experimental and the predicted moisture ratios with the Hii et al. model versus the drying time for dried radish slices at 40,50 and $60{ }^{\circ} \mathrm{C}$. It is observed that, the proposed model provided conformity between the experimental and predicted moisture ratios. Accordingly, this indicates the suitability of Hii et al. model in describing drying behavior of radish slices. The Hii et al. model has also been suggested by others to describe hot-air drying of Pumpkin (Onwude et al. 2016), Native Cassava Starch (Aviara and Igbeka 2016), Apple snails (Du Luo et al. 2015).

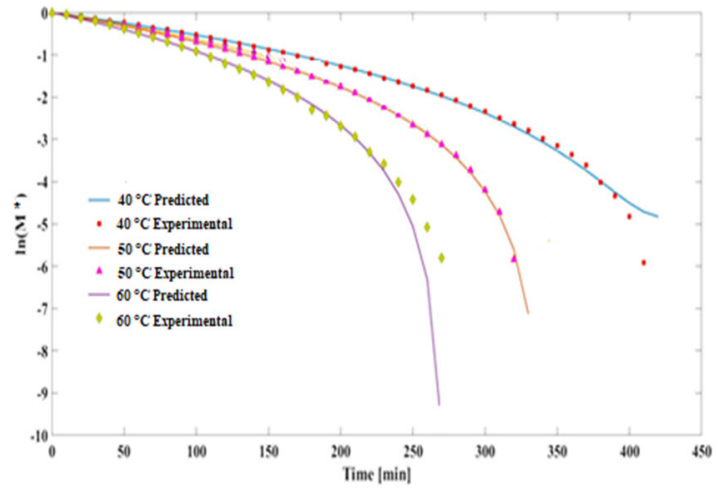

Fig. 5 Experimental and predicted moisture ratios (Hii et al. model) versus drying time

The values of effective diffusivity $\left(D_{\text {eff }}\right)$ at different drying temperatures obtained by using Eq. (7) and the estimated values are presented in Table 4 . The average value of effective diffusivities of radish slices in the drying process at 40,50 and $60{ }^{\circ} \mathrm{C}$ varied in the range of $3.3-5.55 \times 10^{-8} \mathrm{~m}^{2} / \mathrm{min}$. The values of $D_{\text {eff }}$ increased progressively as the drying air temperature increased. It is due to fact that increase in the drying air temperature increases the activity of water particles in the sample slices. As a result, moisture gradient inside the product increases and thus $D_{\text {eff }}$ increases. Similar findings were reported by Sacilik and Elicin (2006), Akpinar and Toraman (2013).

Also, the variation of moisture effective diffusivity $\left(D_{\text {eff }}\right)$ with temperature is illustrated in Figure 6.

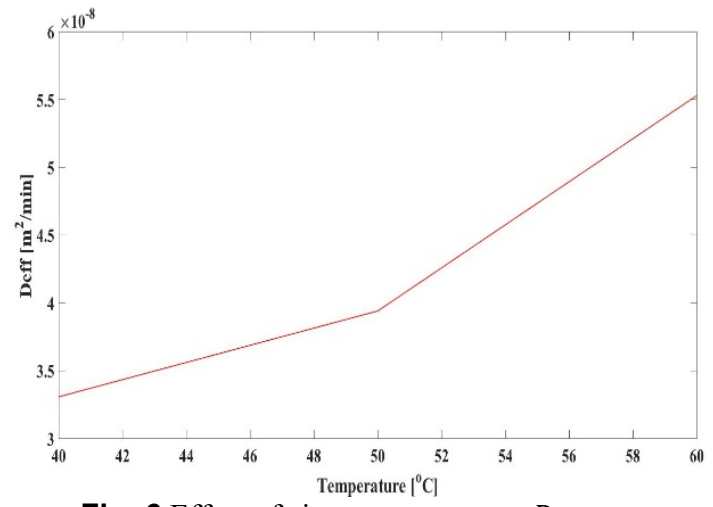

Fig. 6 Effect of air temperature on $D_{e f f}$

The variation of the moisture effective diffusivity $\left(D_{\text {eff }}\right)$ with moisture ratio is shown in Figure 7 . It can be seen that $D_{\text {eff }}$ increases with decrease in moisture ratio and further it can be seen that $D_{\text {eff }}$ increases with increase in drying air temperature.

Table 4 Effective moisture diffusivity values attained at various air temperatures

\begin{tabular}{|c|c|}
\hline$T\left({ }^{\circ} \mathrm{C}\right)$ & $D_{\text {eff }}\left(\mathrm{m}^{2} / \mathrm{min}\right)$ \\
\hline 40 & $3.3085 \times 10^{-8}$ \\
\hline 50 & $3.9418 \times 10^{-8}$ \\
\hline 60 & $5.5301 \times 10^{-8}$ \\
\hline
\end{tabular}

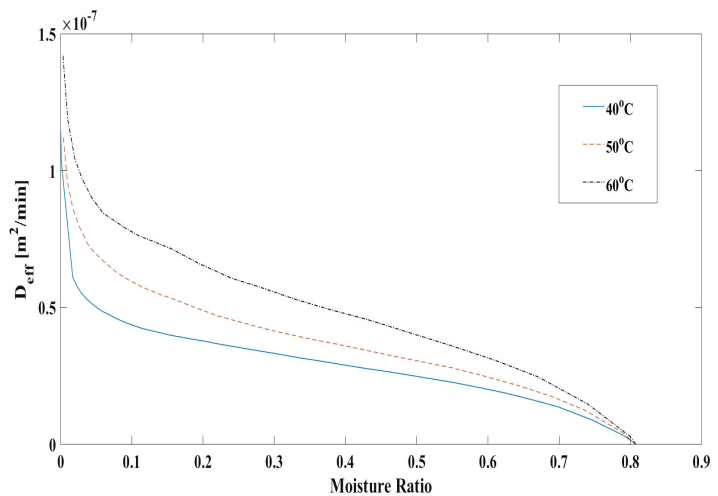

Fig. 7 Variation of effective moisture diffusivity versus moisture ratio at different drying temperatures

The temperature dependence of $D_{\text {eff }}$ can be described by Arrheniustype of relationship as given in Eq. (8). The activation energy $E_{a}$ was calculated from the slope of the plot on $\ln \left(D_{\text {eff }}\right)$ vs $1 / T$ in Figure 8 . It was found to be $18.49 \mathrm{~kJ} / \mathrm{mol}$. The value obtained in this study is in close range of $15-40 \mathrm{~kJ} / \mathrm{mol}$ with various foods reported by Rizvi (1995). The $E_{a}$ of radish slices is close to that of lettuce and cauliflower leaves, mushrooms, red chillies, apple slices and Uryani plums (Lopez et al. 2000, Arora et al. 2003, Kaleemullah and Kailappan 2006, Kaya et al. 2007, Sacilik et al. 2006).

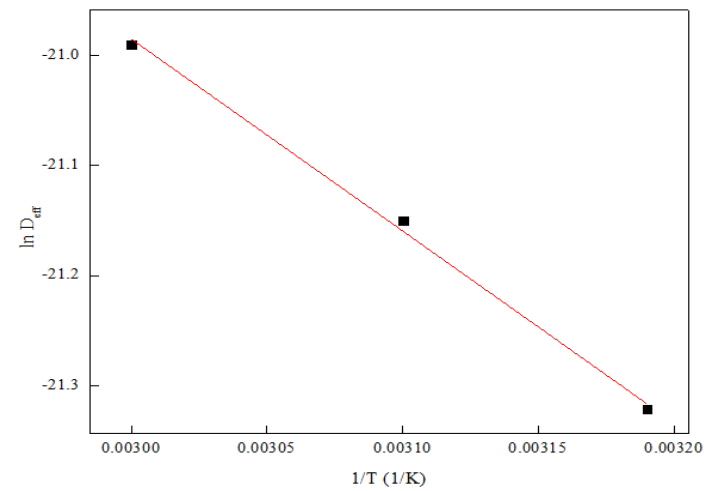

Fig. 8 Temperature dependence of $D_{\text {eff }}$ by Arrhenius relation

\section{CONCLUSIONS}

The drying kinetics of the radish slices were investigated in an induced draft convective tray dryer at the drying air temperatures of 40,50 and $60{ }^{\circ} \mathrm{C}$. Constant drying rate period was not observed, the entire radish drying occurring in the falling rate period. The moisture content and drying rate were influenced significantly by the drying air temperature. Increase in the drying air temperature caused a decrease in the drying time and an increase in the drying rate. The effective diffusivity increased with the increase in the drying air temperature. Based on the non-linear regression analysis, the Hii et al. model was considered adequate to describe the thin-layer behavior of radish slices. The values of calculated effective moisture diffusivity varied from $3.3-5.55 \times 10^{-8} \mathrm{~m}^{2} / \mathrm{min}$ over the temperature range. The effective diffusivity increases as temperature increases. Temperature dependence of the diffusivity values was described by an Arrhenius-type relationship. The activation energy for moisture diffusion was found to be $18.49 \mathrm{~kJ} / \mathrm{mol}$.

\section{ACKNOWLEDGEMENTS}

Authors acknowledge the Koneru Lakshmaiah Education Foundation for providing financial support 


\section{NOMENCLATURE}

$D_{e f f} \quad$ effective moisture diffusivity $\left(\mathrm{m}^{2} / \mathrm{min}\right)$

$D_{o} \quad$ pre-exponential factor of Arrhenius equation $(\mathrm{kJ} / \mathrm{mol})$

$E_{a} \quad$ activation energy $(\mathrm{kJ} / \mathrm{mol})$

exp, $i \quad \mathrm{i}^{\text {th }}$ experimental moisture ratio value

$M_{\tau} \quad$ moisture content at any time ( $\left.\mathrm{kg} \mathrm{w} / \mathrm{kg} \mathrm{ds}\right)$

$M_{e} \quad$ equilibrium moisture content $(\mathrm{kg} \mathrm{w} / \mathrm{kg} \mathrm{ds})$

$M_{o} \quad$ initial moisture content $(\mathrm{kg} \mathrm{w} / \mathrm{kg} \mathrm{ds})$

$M^{*} \quad$ fractional moisture ratio

$N \quad$ number of observations

pre, $i \quad \mathrm{i}^{\text {th }}$ predicted moisture ratio value

$R^{2} \quad$ coefficient of determination

$R M S E \quad$ root mean square error

$R \quad$ universal gas constant $(8.314 \mathrm{~J} / \mathrm{mol} \mathrm{K})$

$T \quad$ temperature $\left({ }^{\circ} \mathrm{C}\right)$

Greek Symbols

$\tau \quad$ drying time ( $\mathrm{min})$

\section{REFERENCES}

Abhishek, D., Ramakrishna, K., and Naveen, P., 2019, "Method for determining the appropriate thin layer drying model for a feedstock", International Journal of Recent Technology and Engineering, 8(3), 3627-3632. https://dx.doi.org/10.35940/ijrte.C53350.098319

Agarry, S. E., Ajani, A. O., and Aremu, M. O., 2013, “Thin layer drying kinetics of pineapple: Effect of blanching temperature-time combination", Nigerian Journal of Basic and Applied Science, 21(1), 110. https://dx.doi.org/10.4314/njbas.v21i1.1

Akpinar, E., Midilli, A., and Bicer. Y., 2003, "Single layer drying behavior of potato slices in a convective cyclone dryer and mathematical modeling", Energy Conversion and Management, 44(10), 1689-1705. https://doi.org/10.1016/S0196-8904(02)00171-1

Akpinar, E.K., Bicer, Y., and Cetinkaya, F., 2006, "Modelling of thin layer drying of parsley leaves in a convective dryer and under open sun", Journal of Food Engineering, 75(3), 308-315.

https://doi.org/10.1016/j.jfoodeng.2005.04.018

Akpinar, E.K., and Toraman, S., 2016, "Determination of drying kinetics and convective heat transfer coefficients of ginger slices", Heat and Mass Transfer, 52(10), 2271-2281.

https://doi.org/10.1007/s00231-015-1729-6

Anwar, S. I., and Tiwari, G. N., 2001, "Evaluation of convective heat transfer coefficient in crop drying under open sun drying conditions", Energy Conversion and Management, 42(5), 627-637.

https://doi.org/10.1016/S0196-8904(00)00065-0.

Akoy, E.O., 2014, "Experimental characterization and modeling of thinlayer drying of mango slices", International Food Research Journal 21(5), 1911-1917.

Arora, S., Shivhare, U. S., Ahmed, J., and Raghavan, G. S. V., 2003, "Drying kinetics of Agaricus bisporus and pleurotus florida mushrooms", Transactions- American Society of Agricultural Engineers, 46(3), 721724.

Aregbesola, O. A., Ogunsina, B., Sofolahan, A. E., and Chime, N. N., 2015, "Mathematical modeling of thin layer drying characteristics of dika (Irvingia gabonensis) nuts and kernels", Nigerian Food Journal, 33(1), 83-89. https://doi.org/10.1016/j.nifoj.2015.04.012

Aviara, N. A., and Igbeka, J. C., 2016, "Modeling for drying of thin layer of native cassava starch in tray dryer", Journal of Biosystems Engineering, 41(4), 342-356.

https://doi.org/10.5307/JBE.2016.41.4.342
Ayadi M., Ben Mabrouk, S., Zouari, I., and Bellagi A., 2014, "Kinetic study of the convective drying of spearmint", Journal of Saudi Society of Agricultural Sciences, 13(1), 1-7. https://doi.org/10.1016/j.jssas.2013.04.004

Benjamin Caballero, Trugo Luiz and Paul M. Finglas., 2003, The Encyclopedia of Food Sciences and Nutrition, $2^{\text {nd }}$ ed., Academic Press, London.

Correia, A. F. K., Loro, A. C., Zanatta, S., Spoto, M. H. F., and Vieira, T. M. F. S., 2015, "Effect of temperature, time and material thickness on the dehydration process of tomato", International Journal of Food Science, 2015, Article ID 970724, 1-7. https://dx.doi.org/10.1155/2015/970724

Crank J., 1975, The Mathematics of Diffusion, $2^{\text {nd }}$ ed., Clarendon Press, UK.

Daniel I. Onwude, Hashim, N., Nazmi, M. N., and Khalina, A., 2016, "Evaluation of a suitable thin layer model for drying of pumpkin under forced air convection", International Food Research Journal, 23(3), 1173-1181.

Darvishi, H., Farhudi, Z., and Nasser Behroozi-Khazaei, 2016, "Mass transfer parameters and modelling of hot air-drying kinetics of dill leaves", Chemical Product and Process Modeling, 12(2), 1-8. https://doi.org/10.1515/cppm-2015-0079

Doymaz, I., 2007, "The kinetics of forced convective air-drying of pumpkin slices", Journal of Food Engineering, 79(1), 243-248. https://doi.org/10.1016/j.jfoodeng.2006.01.049

Du Luo, Haitao Zhang, Xidong Mu, et al., 2015, "Modeling of efficient hot air drying of apple snails (pomacea canaliculate) for use as a fishmeal protein substitute", Advance Journal of Food Science and Technology, 8(3), 193-201. https://doi.org/10.19026/ajfst.8.1491

El-Beltagy A., Gamea G.R., and Essa A. H. A., 2007, "Solar drying characteristics of strawberry", Journal of Food Engineering, 78(2), 456464. https://doi.org/10.1016/j.jfoodeng.2005.10.015

Gokhale, S. V., and Lele, S. S., 2011, "Dehydration of red beet root (Beta vulgaris) by hot air drying: Process optimization and mathematical modeling", Food Science and Biotechnology, 20(4), 955-964. https://doi.org/10.1007/s10068-011-0132-4

Hashim, N., Onwude, D., and Rahaman, E., 2014, “A preliminary study: kinetic model of drying process of pumpkins (Cucurbita moschata) in a convective hot air dryer", Agriculture and Agricultural Science Procedia, 2(2), 345-352. https://doi.org/10.1016/j.aaspro.2014.11.048

Kaleeullah, S., and Kailappan, R., 2006, "Modelling of thin-layer drying kinetics of red chilies", Journal of Food Engineering, 76, 531-537. https://doi.org/10.1016/j.jfoodeng.2005.05.049

Kaya, A., Aydin, O., Demirtas, C., and Akgun, M., 2007, "An experimental study on the drying kinetics of quince", Desalination, 212(1-3), 328-343. https://doi.org/10.1016/j.desal.2006.10.017

Kavak Akpinar, E., 2002, "The development of a cyclone type dryer for agricultural products", Ph.D. Thesis, Firat University, Elazig, Turkey.

Kaymk-Ertekin, F., 2002, "Drying and rehydrating kinetics of green and red peppers", Journal of Food Science, 67, 168-175. https://doi.org/10.1111/j.1365-2621.2002.tb11378.x

Kiran Naik, B., Muthukumar, P., and Bhattacharyya, C., 2019, "Thermal modelling and parametric investigations on coupled heat and mass transfer processes occurred in a packed tower", Heat and Mass Transfer, 55, 627-644. https://doi.org/10.1007s00231-018-2440-1 
Kulwinder, K., and Singh, A. K., 2014, "Drying kinetics and quality characteristics of beetroot slices under hot air followed by microwave finish drying", African Journal of Agricultural Research, 9(12), 10361044. https://doi.org/10.5897/AJAR2013.7759

Kumar, N., Sarkar, B. C., and Sharma, H. K., 2012b, "Mathematical modeling of thin-layer hot air drying of carrot pomace", Journal of Food Science and Technology, 49(1), 33-41.

https://doi.org/10.1007/s13197-011-0266-7

Lahsasni, S., Kouhila, M., Mahrouz, M., and Jaouhari, J.T., 2004, "Drying kinetics of prickly pear fruit (Opuntia ficus indica)", Journal of Food Engineering, 61(2), 173-179.

\section{https://doi.org/10.1016/S0260-8774(03)00084-0}

Lee, W. Y., Cha, W. S., Oh, S. L., Cho, Y. J., Lee, H. Y., Lee, B. S., et al., 2006, "Quality characteristics of dried radish (Raphanus sativus) by drying methods", Korean Journal of Food Preservation, 13, 37-42.

Lopez, A., Iguaz, A., Esnoz, A., and Virseda, P., 2000, “Thin-layer drying behaviour of vegetable wastes from wholesale market", Drying Technology, 18(4-5), 995-1006. https://doi.org/10.1080/07373930008917749

Madamba, P.S., Driscoll, R.H., and Buckle, K.A., 1996, “ The thin-layer drying characteristics of garlic slices", Journal of Food Engineering, 29, 75-97. https://doi.org/10.1016/0260-8774(95)00062-3

Manuel Cuevas, María Lourdes Martínez-Cartas, Luis Pérez-Villarejo, Lucía Hernández, Juan Francisco García-Martín, and Sebastián Sánchez, 2019, "Drying kinetics and effective water diffusivities in olive stone and olive-tree pruning", Renewable Energy, 132, 911-920.

https://doi.org/10.1016/j.renene.2018.08.053

Midilli, A., 2001a, "Determination of pistachio drying behavior and conditions in a solar drying system", International Journal of Energy Research, 25(8), 715-725. https://doi.org/10.1002/er.715

Midilli, A., 2001b, "Wastewater distillation by using natural vacuum technique", Ph.D. Thesis, Karadeniz Technical University, Trabzon, Turkey.

Midilli, A., Kucuk, H., and Yapar, Z., 2002, "A new model for singlelayer drying”, Drying Technology, 20(7), 1503-1513.

https://doi.org/10.1081/DRT-120005864

Omolola, A. O., Jideani, A. I. O., and Kapila, P. F., 2014, "Modeling microwave-drying kinetics and moisture diffusivity of Mabonde banana variety", International Journal of Agricultural and Biological Engineering, 7(6), 107-113.

https://doi.org/10.3965/i.ijabe.20140706.013

Özbek, B., and Dadali, G., 2007, "Thin-layer drying characteristics and modelling of mint leaves undergoing microwave treatment", Journal of Food Engineering, 83(4), 541-549.

https://doi.org/10.1016/j.jfoodeng.2007.04.004
Ratiya, T., Somkiat, P., Jaruwan, K., and Somchart, S., 2011, "Determination of effective moisture diffusivity and assessment of quality attributes of banana slices during drying", LWT-Food Science and Technology, 44(6), 1502-1510.

https://doi.org/10.1016/j.lwt.2011.01.003

Rizvi SSH., 1995, "Thermodynamic properties of foods in dehydration". In: Rao MA, Rizvi SSH, editors. Engineering properties of foods, Marcel Dekker, New York, 223-309.

Sacilik, K., Keskin, R., and Elicin, A. K., 2006, "Mathematical modeling of solar tunnel drying of thin-layer organic tomato", Journal of Food Engineering, 73, 231-238.

https://doi.org/10.1016/j.jfoodeng.2005.01.025

Sacilik, K., 2007, "Effect of drying methods on thin-layer drying characteristics of hull-less seed pumpkin (Cucurbita pepo L.)", Journal of Food Engineering, 79(1), 23-30.

https://doi.org/10.1016/j.jfoodeng.2006.01.023

Samira, N., Nasrin, E., Arefe, P. N., and Majid, G. F., 2016, "Mathematical modeling of drying of potato slices in a forced convective dryer based on important parameters", Food Science and Nutrition, 4(1), 110-118. https://doi.org/10.1002/fsn3.258

Vedavathi, N., Dharmaiah, G., Balamurugan, K. S., and Ramakrishna, K., 2019, "A study on MHD boundary layer flow rotating frame nanofluid with chemical reaction", Frontiers in Heat and Mass Transfer, 12, 10, 1-9. http://dx.doi.org/10.5098/hmt.12.10

Waheed, M. A., and Komolafe, C. A., 2019, "Temperatures dependent drying kinetics of cocoa beans varieties in air-ventilated oven", Frontiers in Heat and Mass Transfer, 12,8, 1-7.

http://dx.doi.org/10.5098/hmt.12.8

Wang, Z., Sun, J., Liao, X., Chen, F., Zhao, G., Wu, J., and Hu, X., 2007a, "Mathematical modeling on hot air drying of thin layer apple pomace", Food Research International, 40(1), 39-46. https://doi.org/10.1016/j.jfoodres.2006.07.017

Wang, Z., Sun, J., Chan, F., Liao, X., and Hu, X., 2007b, "Mathematical modelling on thin layer microwave drying of apple pomace with and without hot air pre-drying", Journal of Food Engineering, 80(2), 536544. https://doi.org/10.1016/j.jfoodeng.2006.06.019

Xiao-Kang Yi, Wen-Fu Wu, Ya-Qiu Zhang, Jun-Xing Li and Hua-Ping Luo, 2012, "Thin-layer drying characteristics and modelling of Chinese Jujubes", Mathematical Problems in Engineering, 2012, Article ID 386214, 1-18. https://doi.org/10.1155/2012/386214

Yaldiz, O., Ertekin, C., and Uzun, H. I., 2001, "Mathematical modeling of thin-layer solar drying of sultana grapes", Energy, 26(5), 457-65. https://doi.org/10.1016/S0360-5442(01)00018-4

Yald'yz, O., and Ertek'yn, C., 2007, “Thin-layer solar drying of some vegetables”, Drying Technology, 19(3-4), 583-97.

https://doi.org/10.1081/DRT-100103936 